Sains Malaysiana 51(1)(2022): 187-198

http://doi.org/10.17576/jsm-2022-5101-15

\title{
Pleurotus pulmonarius (Fr.) Quel Crude Aqueous Extract Ameliorates Wistar-Kyoto Rat Thoracic Aortic Tissues and Vasodilation Responses
}

(Pleurotus pulmonarius (Fr.) Quel Ekstrak Akueus Mentah dalam Memperbaiki Tisu Toraks Aorta dan Respons Vasodilatasi Tikus Wistar-Kyoto)

Noor Fazila Mohd Yahaya, Norhaniza AminUdin* \& NOORLIDAH AbDUllaH

\begin{abstract}
Pleurotus pulmonarius crude aqueous (CA) extract was previously reported to have therapeutic potential, thus its ability to alleviate serum total cholesterol, vasodilation, and improve the aortic tissue structure in hypercholesterolemia rat model was studied. Eight groups of Wistar-Kyoto rats were involved including normal (G1), hypercholesterolemia (G2), treatment (G3 to G5) and prevention (G6 to G8). Two doses of CA; $0.5 \mathrm{~g} / \mathrm{kg} \mathrm{body} \mathrm{weight} \mathrm{(BW),} 2.0 \mathrm{~g} / \mathrm{kg} \mathrm{BW,} \mathrm{and}$ simvastatin $10 \mathrm{mg} / \mathrm{kg} \mathrm{BW}$ were orally fed to the rats (G3 to G8). Treatment groups were induced with hypercholesterolemia and later treated with CA/simvastatin, while prevention groups were given both hypercholesterolemia-diet and CA/ simvastatin simultaneously. The thoracic aortic rings (TAR) were subjected to contractility study and histopathology examination. In organ bath analysis, pre-contracted TAR of G1 with phenylephrine (PE) achieved 60\% vasodilation response towards acetylcholine (ACh) whereas TAR of G2 unable to respond to ACh. G3 to G5 groups failed to dilate when induced with ACh whereas G6 to G8 groups showed a slight improvement. The repeated precontracted TAR of $G 1$ and G2 significantly dilated with the presence of CA and simvastatin. TAR of G1 achieved 100\% vasodilation at $3.0 \mathrm{mg} / \mathrm{mL} \mathrm{CA}$ and $2.4 \mathrm{mg} / \mathrm{mL}$ simvastatin. TAR of G2 achieved $73 \%$ vasodilation at $6.0 \mathrm{mg} / \mathrm{mL} \mathrm{CA} \mathrm{whereas} 76.8 \%$ dilation recorded for simvastatin at $4.8 \mathrm{mg} / \mathrm{mL}$. Histopathological examination found that CA was able to improve the structure of the aortic cells. These observations suggest that CA helps to improve tissue condition and vasodilation of the hypercholesterolemic aorta.
\end{abstract}

Keywords: Aortic ring; crude aqueous; dilation; histopathology; hypercholesterolemia

ABSTRAK

Ekstrak akueus mentah Pleurotus pulmonarius (CA) pernah dilaporkan sebelum ini mempunyai potensi terapi, oleh itu keupayaannya untuk mengurangkan kolesterol total serum, vasodilasi dan memperbaiki struktur tisu aorta pada model tikus hiperkolesterolemia telah dikaji. Lapan kumpulan tikus Wistar-Kyoto yang terlibat termasuklah normal (G1), hiperkolesterolemia (G2), rawatan (G3 hingga G5) dan pencegahan (G6 hingga G8). Dua dos CA; $0.5 \mathrm{~g} / \mathrm{kg}$ berat badan (BW), $2.0 \mathrm{~g} / \mathrm{kg} \mathrm{BW}$ dan simvastatin $10 \mathrm{mg} / \mathrm{kg} \mathrm{BW}$ telah diberi makan secara oral kepada tikus (G3 hingga G8). Kumpulan rawatan telah diaruh dengan hiperkolesterolemia dan kemudian dirawat dengan CA/simvastatin, manakala kumpulan pencegahan telah diberi diet-hiperkolesterolemia dan CA/simvastatin secara serentak. Cincin aorta toraks (TAR) telah digunakan untuk kajian kontraktiliti dan pemeriksaan histopatologi. Dalam analisis mandi organ, pra-kontrak TAR G1 dengan fenilefrina-(PE) telah mencapai $60 \%$ tindak balas vasodilasi terhadap asetilkolina (ACh), sementara TAR G2 tidak memberikan sebarang tindak balas terhadap ACh. Kumpulan G3 hingga G5 gagal untuk dilat apabila diaruh dengan ACh manakala kumpulan G6 hingga G8 menunjukkan sedikit peningkatan. Ulangan pra-kontrak TAR G1 dan $G 2$ dilat secara signifikan dengan kehadiran CA dan simvastatin. TAR G1 telah mencapai 100\% vasodilatasi pada $3.0 \mathrm{mg} / \mathrm{mL} \mathrm{CA}$ dan $2.4 \mathrm{mg} / \mathrm{mL}$ simvastatin. TAR G2 telah mencapai 73\% vasodilatasi pada $6.0 \mathrm{mg} / \mathrm{mL} \mathrm{CA} \mathrm{sedangkan}$ $76.8 \%$ dilat dicatatkan untuk simvastatin pada $4.8 \mathrm{mg} / \mathrm{mL}$. Pemeriksaan histopatologi mendapati CA dapat memperbaiki struktur sel aorta. Pemerhatian ini mencadangkan CA membantu untuk memperbaiki keadaan tisu dan vasodilatasi aorta hiperkolesterolemia.

Kata kunci: Akueus mentah; cincin aorta; dilat; hiperkolesterolemia; histopatologi 


\section{INTRODUCTION}

Hypercholesterolemia is one of the major contributors to cardiovascular diseases (CVD). High cholesterol level in the body relates to high proportion of low-density lipoprotein (LDL) which is very susceptible to oxidation by reactive oxygen species (ROS). The reactive chain will lead to plaque accumulation in blood vessel, thus causes blood vessel narrowing and stiffness. This condition will lead to hypertension and ultimately ischemic heart disease (IHD). IHD is one of the most common forms of heart diseases. These chains of multiple diseases development are possible if hypercholesterolemia is left untreated (Bhutia et al. 2019; Murray 2009).

Pleurotus spp. also had been discovered as potential anti-hypercholesterolemic agent and as powerful antioxidant in many findings. Pleurotus spp. is a wellknown mushroom with high nutrients, wonderful taste and validated bioactivities (Anwar et al. 2019; Choi et al. 2017). It has received tremendous interest worldwide since the recorded publication on Pleurotus spp. has spiked from 15 articles in 1985 to 788 articles in 2015 (Correa et al. 2016). Pleurotus spp. is a good source of protein need for vegetarians due to the high protein content (Pleurotus sapidus, 38.5\%; Pleurotus geesteranus, 30.3\%; Pleurotus citrinopileatus, 29.4\%; Pleurotus sajor-caju, 26.0\%; Pleurotus ostreatus, 23.0\%; Pleurotus pulmonarius, 22.9\%; Pleurotus tuber-regium 10.8\%) (Carrasco-Gonzalez et al. 2017; Guillamón et al. 2010).

Pleurotus florida has been shown to ameliorate weight gain in hypercholesterolemic-induced rats besides reducing their atherogenic index by secreting accumulated lipid through faecal matter (Fombang et al. 2016). High density lipoprotein-cholesterol (HDL-C) was also reported to be increased which favoured cholesterol homeostasis through reverse-transportation of lipoprotein to the liver. Another study also claimed the promising feature of Pleurotus ferulae in reducing serum total cholesterol, triglyceride and LDL in hypercholesterolemic rats (Alam et al. 2011). In addition, it has been proven that $P$. ostreatus consumption by the diabetic patients significantly reduced their total cholesterol and triglycerides with additional value by reducing blood pressure with no toxicity effect on liver and kidney (Khatun et al. 2007).

Other findings also reported the ability of the mushroom extract in vitality of vasculature. Aqueous extract of $P$. sajor-caju was found to carry angiotensin1converting enzyme (ACE) inhibitor thus normalize blood pressure in the studied rats' model (Abdullah et al. 2012).
The protein fraction of $P$. pulmonarius orally fed to the spontaneous hypertensive rats (SHRs) found to be able to reduce systolic blood pressure (SBP) $33.5 \mathrm{~mm} \mathrm{Hg}$ in SHRs. Molecular docking analysis by Manoharan et al. (2018) resulted in identification of gastrointestinal (GI) enzymes, tripeptide GVR with the ability to execute as ACE inhibitor.

In Malaysia, $P$. pulmonarius mushroom has been recognised as one of the functional foods with vast benefits to the human health. Functional food is a term introduced by International Life Sciences Institute (ILSI Europe) which refers to a food that can provide potential benefits and protect organs from possible damage due to many factors including hypercholesterolemia (Ey et al. 2007). Crude aqueous extract (CA) of $P$. pulmonarius was found to be fortified with antioxidants properties and a powerful ROS scavenger which protecting the endothelial cells and human LDL from oxidation which was confirmed via in vitro observation (Abidin et al. 2016). The aim of this study was to verify the ability of CA from $P$. pulmonarius to alleviate serum total cholesterol and assist vasodilation in thoracic rat aorta besides contributing to viability of the aortic ring tissue and its structure.

\section{MATERIALS AND Methods}

\section{MUSHROOM MATERIAL}

The locally known grey oyster mushroom or $P$. pulmonarius were purchased from Agro-tech Sdn. Bhd, Selangor, Malaysia. The species were previously identified as $P$. pulmonarius based on the morphological characteristic and via DNA online sequence data. Culture was registered as KUM61119 and maintained at the Mycological Laboratory, Mushroom Research Centre, Universiti Malaya. A voucher of the mushroom specimen was deposited in Universiti Malaya Herbarium and registered as KLU-M1234.

\section{MUSHROOM EXTRACTION}

Pleurotus pulmonarius fruiting bodies were shredded into small pieces prior to freeze-drying. Following freeze-drying process, the sample was ground into fine powder and soaked in distilled water at a ratio of 1:10 (w/v) overnight at $2-8^{\circ} \mathrm{C}$. Later, it was sieved to collect the liquid and the residue was discarded. The collected liquid was centrifuged at $5000 \mathrm{rpm}$ for $20 \mathrm{~min}$ and the clear supernatant was freeze-dried. The freeze-dried powder of CA was dissolved in distilled water prior to feeding via oral gavage to the rats (Abidin et al. 2016). 


\section{INDUCTION OF HYPERCHOLESTEROLEMIA IN RAT} MODEL

Forty-eight Wistar-Kyoto rats were purchased from Animal Experimental Unit (AEU), Universiti Malaya aged six weeks $(\sim 200 \mathrm{~g})$. Blood withdrawal from the lateral tail veins tail was done for all the rats on Day 0 .
The procedure below has received approval from FoM IACUC committee (2015-181006/IBS/R/NFMY). All the animals were housed in AEU under 12:12 h light-dark cycle conditioned at $24^{\circ} \mathrm{C}\left( \pm 1^{\circ} \mathrm{C}\right)$. Drink was maintained ad libitum for all the rats. The rats were divided into 8 groups and the diet formulation was adopted from previous research (Chen et al. 2014) (Table 1).

TABLE 1. Diet formulation for all the rats' group

\begin{tabular}{|c|c|c|c|}
\hline No & Group & Category & Diet Description \\
\hline 1 & G1 & Normal & Healthy rats fed with normal food (Day 1 - 45) \\
\hline 2 & $\mathrm{G} 2$ & Hypercholesterolemic & $\begin{array}{l}\text { Rats fed with cholesterol powder* (200 mg/kg BW) dissolved in palm } \\
\text { oil }(10 \mathrm{~mL} / \mathrm{kg} \mathrm{BW})(\text { Day } 1-45)+\mathrm{CA}(0.5 \mathrm{~g} / \mathrm{kg} \mathrm{BW})(\text { Day } 46-75)\end{array}$ \\
\hline 3 & G3 & Treatment 1 & $\begin{array}{l}\text { Rats fed with cholesterol powder* }(200 \mathrm{mg} / \mathrm{kg} \mathrm{BW}) \text { dissolved in palm } \\
\text { oil }(10 \mathrm{~mL} / \mathrm{kg} \mathrm{BW})(\text { Day } 1-45)+\mathrm{CA}(0.5 \mathrm{~g} / \mathrm{kg} \mathrm{BW})(\text { Day } 46-75)\end{array}$ \\
\hline 4 & G4 & Treatment 2 & $\begin{array}{l}\text { Rats fed with cholesterol powder* (200 mg/kg BW) dissolved in palm } \\
\text { oil }(10 \mathrm{~mL} / \mathrm{kg} \mathrm{BW})(\text { Day } 1-45)+\mathrm{CA}(2.0 \mathrm{~g} / \mathrm{kg} \mathrm{BW})(\text { Day } 46-75)\end{array}$ \\
\hline 5 & G5 & Treatment 3 & $\begin{array}{c}\text { Rats fed with cholesterol powder* }(200 \mathrm{mg} / \mathrm{kg} \mathrm{BW}) \text { dissolved in palm } \\
\text { oil }(10 \mathrm{~mL} / \mathrm{kg} \mathrm{BW})(\text { Day } 1-45)+\operatorname{simvastatin} 10 \mathrm{mg} / \mathrm{kg} \mathrm{BW} \text { (Day } 46- \\
75)\end{array}$ \\
\hline 6 & G6 & Prevention 1 & $\begin{array}{l}\text { Rats fed with cholesterol powder* }(200 \mathrm{mg} / \mathrm{kg} \mathrm{BW}) \text { dissolved in palm } \\
\text { oil }(10 \mathrm{~mL} / \mathrm{kg} \mathrm{BW})+\mathrm{CA}(0.5 \mathrm{~g} / \mathrm{kg} \mathrm{BW})(\text { simultaneously) (Day } 1-45)\end{array}$ \\
\hline 7 & G7 & Prevention 2 & $\begin{array}{l}\text { Rats fed with cholesterol powder* (200 mg/kg BW) dissolved in palm } \\
\text { oil }(10 \mathrm{~mL} / \mathrm{kg} \mathrm{BW})+\mathrm{CA}(2.0 \mathrm{~g} / \mathrm{kg} \mathrm{BW})(\text { simultaneously) (Day } 1-45)\end{array}$ \\
\hline 8 & G8 & Prevention 3 & $\begin{array}{l}\text { Rats fed with cholesterol powder* (200 mg/kg BW) dissolved in palm } \\
\text { oil }(10 \mathrm{~mL} / \mathrm{kg} \mathrm{BW})+\text { simvastatin } 10 \mathrm{mg} / \mathrm{kg} \mathrm{BW} \text { (simultaneously) (Day } \\
1-45)\end{array}$ \\
\hline
\end{tabular}

*Cholesterol powder 95\% stabilized; Brand: Acros Organics

Oral gavage was carried out for 45 days for G1, G2, G6, G7, and G8 whereas G3, G4, and G5 lasted till Day 75 (Dikshit et al. 2016). The rats were sacrificed and whole blood was collected through cardiac puncture, centrifuged at $3000 \mathrm{rpm}$ for $10 \mathrm{~min}$ and the serum finally sent to Institute of Medical Veterinary, Universiti Putra Malaysia for serum cholesterol quantification (Automatic Chemistry Analyzer: Siemens Dimension Xpand Plus). 
The thoracic aorta was dissected out from the rats, cleaned from the connective tissues and segmented into several 3 - $4 \mathrm{~mm}$ rings. The thoracic aortic rings (TAR) were then subjected to two different experiments; contractility study and histopathology examination.

\section{TISSUE CONTRACTILITY STUDY USING ORGAN BATH TECHNIQUE}

TAR for contractility study were preserved in KrebsHeinseleit buffer solution (mM: $118 \mathrm{NaCl}, 4.7 \mathrm{KCl}$, $2.5 \mathrm{CaCl}_{2}, 1.2 \mathrm{MgSO}_{4}, 1.2 \mathrm{KH}_{2} \mathrm{PO}_{4}, 25 \mathrm{NaHCO}_{3}, 11.1$ Glucose; 0.25 EDTA) for approximately $10 \mathrm{~min}$. TAR was then mounted in the organ bath chamber filled with $30 \mathrm{~mL}$ of Krebs-Heinseleit buffer solution. The chamber was continuously aerated with carbogen (95\% oxygen: $5 \%$ carbon dioxide) and maintained at $37^{\circ} \mathrm{C}$. A baseline tension of $1.50 \mathrm{~g}$ was applied to the TAR and variations in the basal tension were recognised with a $50 \mathrm{~g}$ force transducer (ADInstruments Pty Ltd, Bella Vista, Australia) coupled with PowerLab 4/35 (ADInstruments, Australia) and let to equilibrate for $45 \mathrm{~min}$. The solution was changed every $15 \mathrm{~min}$ as a precaution against any interfering metabolite (Qu et al. 2014).

Later, a high concentration of potassium $(\mathrm{KCl})$ $(80 \mathrm{mM})$ was added to the chamber for tissue priming purpose. Once it reached the plateau, TAR was flushed till it achieved the baseline. Later, viability test was assembled on TAR by challenging it with phenylephrine (PE) $(10 \mu \mathrm{M})$ and acetylcholine (ACh) was subsequently administrated to TAR (cumulatively added to the solution in the chamber from 1 to $20 \mu \mathrm{M}$ ) and dilation responses towards ACh were transmitted to LabChart software (Koon et al. 2014; Niazmand et al. 2014). Viability test is the pre-requisite to confirm the vitality of the aortic rings used in this study.

Once the viability test succeeded, TAR of the G1 and G2 were challenged again with PE and CA was then administrated cumulatively $(0.1-6.0 \mathrm{mg} / \mathrm{mL})$ to the solution in the chamber (ex vivo). The purpose was to mimic ACh function to dilate the contracted aortic ring. The whole procedure was repeated using another tissue segment by replacing CA with simvastatin. For G3 to G8 groups, TAR was used for viability test only; in order to observe the responses towards ACh after the rats were orally fed with $\mathrm{CA} /$ simvastatin.

\section{HISTOPATHOLOGY OBSERVATION}

The methods explained below were adopted with some modifications (Sharma et al. 2020; Slaoui \& Fiette 2011).
The segmented aortic ring was immersed in formalin overnight in the sample bottles to ensure the formalin is fully absorbed into the tissues so called as fixation process. This particular process is very much crucial to halt autolysis process in order to preserve the tissues for examination. Later, the fixed tissues were dehydrated by soaking them in a series of ethanol with different concentration. The step commenced with soaking the tissues in lowest concentration of ethanol; $80 \%$ for $2 \mathrm{~h}$ followed by $95 \%$ for $2 \mathrm{~h}$ and ended up with $100 \%$ for $3 \mathrm{~h}$.

The paraffin was heated till it reached its melting point around $57{ }^{\circ} \mathrm{C}$ and poured into Leica EG1150 H heated paraffin dispensing module. The tissues were positioned properly to make sure the paraffin fully covered them once solidified. Paraffin-embedded tissues blocks were chilled by placing them on ice. Prior to sectioning, trimming process took place at thickness of $10-30 \mu \mathrm{M}$. Later, sectioning was done at the thickness of $4-5 \mu \mathrm{M}$, put in water bath using microscopic slides and stored at upright position in a slide rack and kept in the oven overnight at $37^{\circ} \mathrm{C}$. Deparaffinising process took place prior to staining with Haematoxylin and Eosin (H\&E) for microscopy viewing.

\section{STATISTICAL ANALYSIS}

Data collected was analysed using SPSS Ver. 23.0 (Paired Sample T-test for serum total cholesterol $(\mathrm{p}<0.05)$, OneWay ANOVA $(\mathrm{p}<0.05)$ for $\mathrm{G} 1$ and $\mathrm{G} 2$ responses towards $\mathrm{CA} /$ simvastatin whereas G6 to G8 groups measurement of ACh endothelium-dependent vasodilator analysis was via Two-Way ANOVA) $(\mathrm{p}<0.05)$.

\section{RESULTS AND DISCUSSION}

\section{SERUM TOTAL CHOLESTEROL QUANTIFICATION}

Table 2 shows the serum total cholesterol values of rats in all the groups. The initial total cholesterol ranges of the groups were $1.80-2.00 \mathrm{mmol} / \mathrm{L}$. The serum total cholesterol values increased in accordance with age increment for G1 group (2.53 $\mathrm{mmol} / \mathrm{L})$ as shown in Table 2(A). The average value recorded for the hypercholesterolemic-induced rats (G2 - G5) was $>3.30$ $\mathrm{mmol} / \mathrm{L}$. Within group comparison of Day 0 and Day 45 $(p<0.05)$ was significantly different. In addition, treated groups (G3-G5) managed to reduce its cholesterol level following the treatment as shown in Table 2(B). A significant reduction of total serum cholesterol was between 17.4 and $28.3 \%$ in the treatment groups ( $p<$ $0.05)$. Serum total cholesterol was maintained within the 
normal range $(2.68-3.00 \mathrm{mmol} / \mathrm{L})$ for the prevention groups $(\mathrm{G6}-\mathrm{G} 8)$ as shown in Table $2(\mathrm{C})(\mathrm{p}<0.05)$ thus verified on CA and simvastatin potent effect on cholesterol homeostasis in the bloodstream.

TABLE 2. Serum total cholesterol quantification (mean $\pm \mathrm{SD}$; standard deviation) (mmol/L) in G1 - G8

\begin{tabular}{|c|c|c|c|c|}
\hline \multirow[t]{2}{*}{ A } & & \multicolumn{3}{|c|}{$\mathrm{mmol} / \mathrm{L}$} \\
\hline & & \multicolumn{2}{|r|}{ Day 1} & Day 45 \\
\hline G1 (Normal) & & \multicolumn{2}{|r|}{$1.90 \pm 0.02$} & $2.53 \pm 0.67^{\mathrm{a}}$ \\
\hline G2 (Hypercholestrol) & & \multicolumn{2}{|r|}{$1.89 \pm 0.6$} & $3.83 \pm 1.03^{b}$ \\
\hline \multirow[t]{2}{*}{ B } & & \multicolumn{3}{|c|}{$\mathrm{mmol} / \mathrm{L}$} \\
\hline & & Day 1 & Day 45 & Day 75 \\
\hline \multirow[t]{3}{*}{ Prevention Groups } & G3 & $1.86 \pm 0.06$ & $3.85 \pm 0.12^{\mathrm{c}, \mathrm{d}}$ & $3.18 \pm 0.11$ \\
\hline & G4 & $1.89 \pm 0.67$ & $3.86 \pm 0.97^{\mathrm{e}, \mathrm{f}}$ & $2.95 \pm 0.09$ \\
\hline & G5 & $1.90 \pm 0.70$ & $3.92 \pm 0.10^{\mathrm{g}, \mathrm{h}}$ & $2.81 \pm 0.98$ \\
\hline \multirow[t]{2}{*}{$\mathrm{C}$} & & \multicolumn{3}{|c|}{$\mathrm{mmol} / \mathrm{L}$} \\
\hline & & \multicolumn{2}{|c|}{ Day 1} & Day 45 \\
\hline \multirow[t]{3}{*}{ Prevention Groups } & G6 & \multicolumn{2}{|c|}{$1.91 \pm 0.03$} & $3.00 \pm 0.11^{\mathrm{i}}$ \\
\hline & G7 & \multicolumn{2}{|c|}{$1.89 \pm 0.07$} & $2.78 \pm 0.97^{\mathrm{j}}$ \\
\hline & G8 & \multicolumn{2}{|c|}{$1.90 \pm 0.07$} & $2.68 \pm 0.06^{\mathrm{k}}$ \\
\hline
\end{tabular}

Letter a-k represented within group comparison [a-b and i-k represented significant differences $(\mathrm{p}<0.05)$ between Day 0 and Day 45 ; c-h represents significant differences $(\mathrm{p}<0.05)$ between Day 0 and Day 45/Day 45 and Day 75 when analysed using Paired Sample T-test. The values are expressed in mean \pm SD; SD: Standard Deviation

A reduction in serum total cholesterol in observed groups of G3 to G8 confirmed the contribution of CA properties. The CA extract used in this study was previously found to be enriched with many beneficial constituents including ergothioneine, tryptophan and ellagic acid (Abidin et al. 2016). Thus, these constituents executed their functions to reduce serum total cholesterol in the observed rat groups. Ellagic acid for instance, was orally fed to the hypercholesterolemic rats and a reduction in serum total cholesterol was recorded although LDL and triglyceride level remained (Ding et al. 2014). In addition, ergothioneine also actively involved in cholesterol breakdown in hepatic cells (Cheah et al. 2016). Besides, previous researchers who worked on Pleurotus spp. also have discovered anti-hypercholesterolemic properties in this particular mushroom species. They reported the ability of another species of Plerutous, $P$. florida to reduce serum total cholesterol in hypercholesterolemic-induced rats
(Fombang et al. 2016). Guillamón et al. (2010) for instance, has summarized many edible mushrooms with various benefits including Pleurotus spp. capability to reduce total cholesterol level.

Besides Pleurotus spp., many mushroom species have been discovered as anti-hypercholesterolemic agent. Lentinus edodes, Agaricus bisporus, and Agaricus brasiliensis are among the mushrooms discovered with potential as anti-hypercholesterolemic agents. A study has summarised that the secondary metabolite, eritadinine from $L$. edodes was found to significantly reduce the cholesterol level in rats by inhibiting S-adenosylhomocysteine hydrolase (SAHH); an enzyme involved in phospholipids metabolism. Eritadinine was also cited as inhibitor of cholesterol HMG-CoA reductase; an enzyme responsible for cholesterol metabolism. Eritadinine was also found to reduce serum lipid level, fat accumulation and plaque formation in the aorta in observed mice (Boonsong et al. 2016; Gil-Ramirez 
et al. 2016; Roncero-Ramos \& Delgado-Andrade 2017). Another study conducted on A. brasiliensis showed its advantages in reducing total cholesterol by promoting the expression of $7 \alpha$-hydroxylase (CYP7A1), ATP-binding cassette subfamily G-transporters (ABCG5/G8) and low-density lipoprotein receptor (LDLR) (de Miranda et al. 2016; Jeong et al. 2010).

\section{VASCULAR VIABILITY TEST ON TAR OF G1 AND G2 AGAINST ACH}

As part of the tissue contractility study using organ bath, the viability test was run on the TAR. The aortic rings were contracted with PE and later dilated by adding ACh. This step is crucial to confirm the viability of the aortic ring for contractility study. Results from viability test showed that the TAR of G1 was able to retain $60 \%$ dilation as shown in Figure 1(a). TAR of G2 showed absence of response towards $\mathrm{ACh}$ and thus, failed in the viability test. The link between rat's ages with its responses towards ACh when TAR was challenged with ACh had been previously established. Young rats (between 4 and 6 weeks) have the potential to achieve $100 \%$ vasodilation when challenged with PE and subsequently with ACh. However, if the rat's age reached 3 to 6 months old, the responses reduced by half to $50 \%$ (Matz et al. 2000).

\section{EX-VIVO TREATMENT OF MUSHROOM}

Both TAR obtained from G1 and G2 were further exposed to CA and simvastatin. Figure 1(b) showed a consistent increase in vasodilation percentage of TAR for G1 as the CA concentration increased. The final $100 \%$ vasodilation was significantly achieved at CA concentration of $3.0 \mathrm{mg} /$ $\mathrm{mL}(\mathrm{p}<0.05)$. The same pattern was observed following treatment with simvastatin, whereby at the concentration of $2.4 \mathrm{mg} / \mathrm{mL}$, the vasodilation of $100 \%$ has been successfully achieved $(\mathrm{p}<0.05)$.

Although TAR of G2 failed to response to ACh during viability test, treatment with CA successfully improve the dilation percentage of TAR. Vasodilation increased in parallel with cumulative CA concentration and finally achieved almost $73.0 \%$ at the CA concentration of $6.0 \mathrm{mg} / \mathrm{mL}$. In comparison, at simvastatin concentration of $4.8 \mathrm{mg} / \mathrm{mL}$, the vasodilation achieved almost $76.8 \%$ $(\mathrm{p}<0.05)$.

\section{VASCULAR VIABILITY TEST ON TAR OF G3 TO G8 AGAINST ACH}

None of the TAR of G3, G4 and G5 dilated when challenged with ACh after pre-constricted with PE during viability test although their serum total cholesterol reduced when treated with $\mathrm{CA} /$ simvastatin. It perhaps due to damage and inability of the blood vessel to dilate even though the serum total cholesterol was significantly alleviated. However, TAR of G6 to G8 had transmitted their contraction and were observed in the LabChart software. Figure 1(c) showed the significant comparison of these three groups where a higher vasodilation percentage was achieved by G7 with $33.9 \%$ followed by G8 (21.7\%) and G6 (14.2\%) with p $<0.05$. Although the responses were not at par with $\mathrm{G} 1$, vasodilation could still be detected. Among the three groups, G7 showed the highest percentage of dilation. From these results, it could be suggested that CA $(2.0 \mathrm{~g} / \mathrm{kg} \mathrm{BW})$ performed better compared to simvastatin.

CA consisted of many beneficial compounds including ergothioniene, tryptophan, and ellagic acid. These compounds pose many potential properties including anti-oxidant and anti-inflammatory (Abidin et al. 2016). Many findings have been reported on ergothioneine role in minimizing cholesterol risk. An observation on guinea pigs with excessive lipid deposit in the liver revealed the accumulation of ergothioniene in the hepatic cells as well. The alleviation of the organic cation transporter N1 (OCTN1) which is the particular ergothioneine transporter was also confirmed the cytoprotective effects of ergothioneine in hepatic tissues (Cheah et al. 2016). Ergothioneine for instance, was reported to inhibit the formation of hydroxyl radicals and lipid peroxidation (Deiana et al. 2004; Li et al. 2014). The ion chelating activity posses by ergothioneine allays the involvement of divalent cation in oxidation cycle. Another publication also verified through metabolomic analysis that ergothioniene has a significant correlation in ameliorating the cardiovascular risk as it is fortified with antioxidant compounds. It also has the ability as free radical scavenger by neutralising the radical into safe compounds thus, interrupts in radical chain (Smith et al. 2020).

Besides ergothioneine, another compound namely ellagic acid was also a potent substance in order to assist vasodilation in blood vessel. CA managed to dilate the blood vessel even though the endothelium layer was damaged which proven the feature of endotheliumindependent in this study. Previous report has cited that ellagic acid has an additional capability to be as an endothelium-dependent and endothelium-independent vasodilator. Endothelium-independent feature is very crucial as the compound is able to dilate the aortic ring without depending on the endothelium viability for vasodilation (Berkban et al. 2015; Devipriya et al. 2007; 
Yilmaz \& Usta 2013). Besides, it was found to imply antiadipogenic effect during adipogenesis in human adipose-derived stem cells (hASCs) (Kang et al. 2016). For instance, a work on oxidized LDL-stimulated J774A1 murine macrophages elicited retardation on the growing macrophage besides blocking the growth of macrophage via the accumulation of foam cells when treated with ellagic acid (Park et al. 1999).
In addition, tryptophan is prominent as inflammatory sensor as its level will spike due to cardiac pathogenesis. The supply of tryptophan during the lesion increased the conversion activity of this particular substance to kynurenine in order to modulate the anti-inflammatory system including blocking atherogenic activity which indirectly reduced further damage to the blood vessel (Song et al. 2017). Many publications cited on

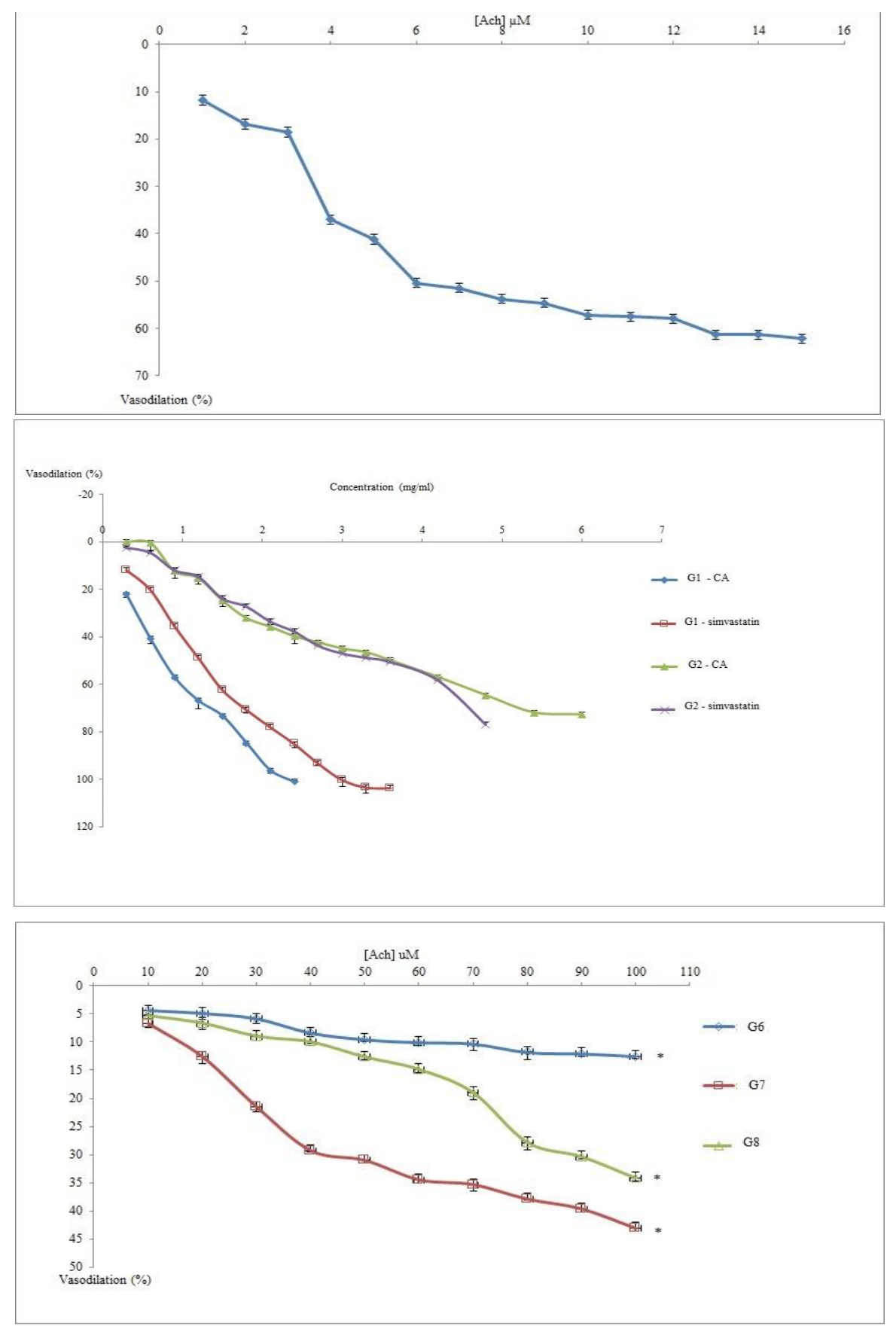

FIGURE 1. Vasodilation percentage of (a) G1 observed during viability test (mean $\pm \mathrm{SD}$ ), (b) G1 and G2 against CA and simvastatin in thoracic aortic ring (TAR) mean $\pm \mathrm{SD}, \mathrm{p}<0.05$ with One-Way ANOVA analysis, and (c) G6-G8 in viability test (mean $\pm \mathrm{SD}, \mathrm{p}<0.05)^{*}$ : there is a significant different among the three group with Two-Way ANOVA analysis $(\mathrm{SD}=$ standard deviation) 
tryptophan and kynurenine contribution in inflammation. Inflammation due cardiovascular lesion was reported to enhance tryptophan degradation to kynurenine, Elevated level of kynurenine-tryptophan ratio was found in the patients' plasma with cardiac lesion. An observation on indoleamine 2,3-dioxygenase (IDO), of the enzyme catalyzes tryptophane to kynurenine in the kynurenine pathway was found to increase the hepatic inflammation when IDO function is interrupted. This study can conclude the importance of tryptophan during inflammation especially due to cardiac lesion (Polyzos \& Ketelhuth 2015).

\section{HISTOPATHOLOGY EXAMINATION ON TAR}

In addition to previous finding on possible compounds exist in CA for cells recovery and viability, histopathology examination is also crucial to confirm the condition of the aortic tissue. Figure 2(a) represents the normal aortic tissue belonged to $\mathrm{G} 1$ with a distinct difference between tunica intimae (TI), tunica media (TM) and tunica adventitia (TA) as labelled. The aortic tissue of G1 was well-structured and the three basic layers; TI, TM, and TA were distinct and no migration of fibrous cap or fatty streak observed. This histopathological observation verified that the tissue fit the classification of a normal aortic tissue and also in accordance with previous report. The research examination on normal artery found a distinct layer of TI beneath the endothelium. Both endothelium and TI are very delicate and prone to damage (Dianita et al. 2016).

G2 unsuccessfully responded to ACh after being challenged with PE; this was due to the endothelial layer have been ruptured. This is appropriately validated through histopathological observation where the aortic tissue was found to be severely damaged. Figure 2(b) shows the condition of aortic tissue of G2 with massive damage. All three layers of TI, TM and TA lost their barriers with the migration of fibrous cap from tunica adventitia to tunica media. Endothelial layer was totally ruptured and
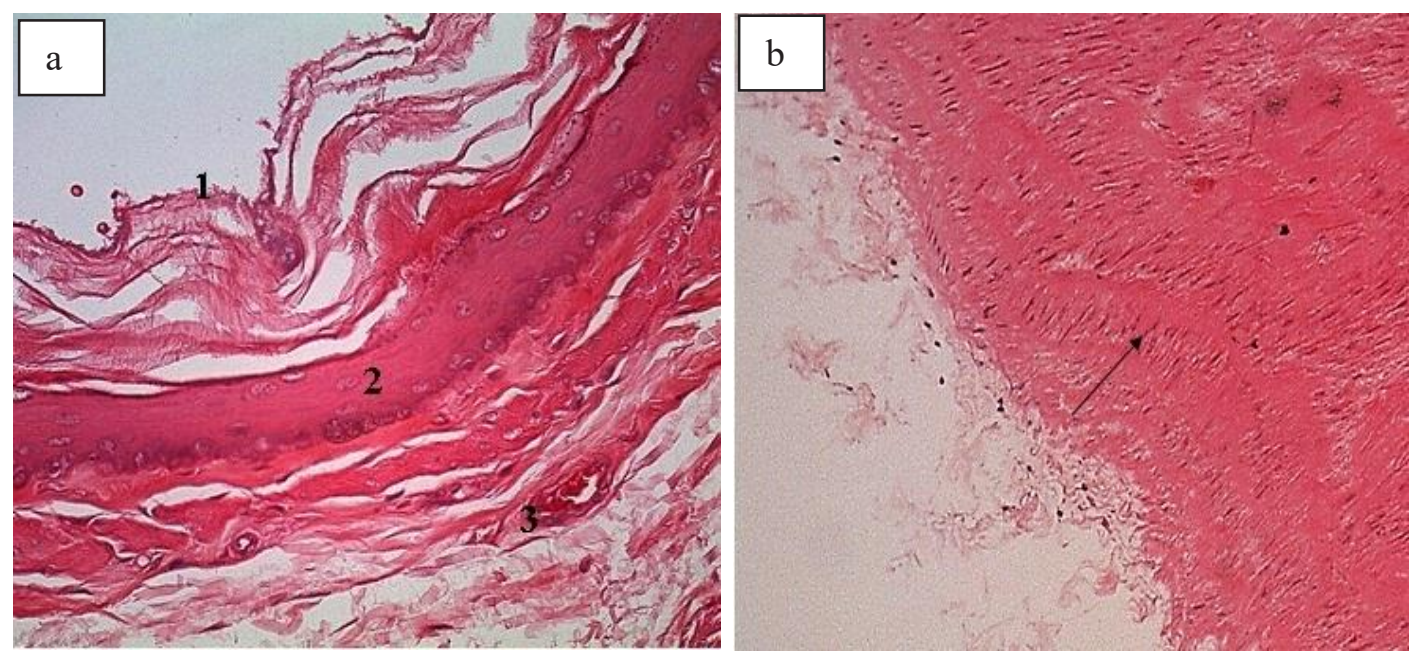

FIGURE 2. Cross section of (a) G1 aortic tissue (1- endothelium or tunica intima;

2- tunica media; 3- tunica adventitia), and (b) G2 aortic tissue (black arrow:

fibrous tissues migration from tunica adventitia to tunica media) (Magnification:

$40 \times)($ scale bar: $200 \mu \mathrm{m})$

was unable to be identified as shown in Figure 2(b). The findings were as reported previously which emphasized on the presence of foam cells with irregular TI in hypercholesterolemic aortic rats (Ahmadi et al. 2017).

In the treatment groups, G3 to G5, the serum total cholesterol was successfully reduced. If compared with G2, the aortic tissues were slightly improved. However, TAR of these groups failed in the viability test against
Ach and through histopathological analysis, it was found that TM was enlarged with fatty streak observed along TI (Figure 3(a) - 3(c)). This observation correlates well with the previous finding. They found an improvement in aortic tissue belonged to rats fed with palm oil although the fatty streak along TI and fat deposits appearance were observed in TM (Ahmadi et al. 2017). 

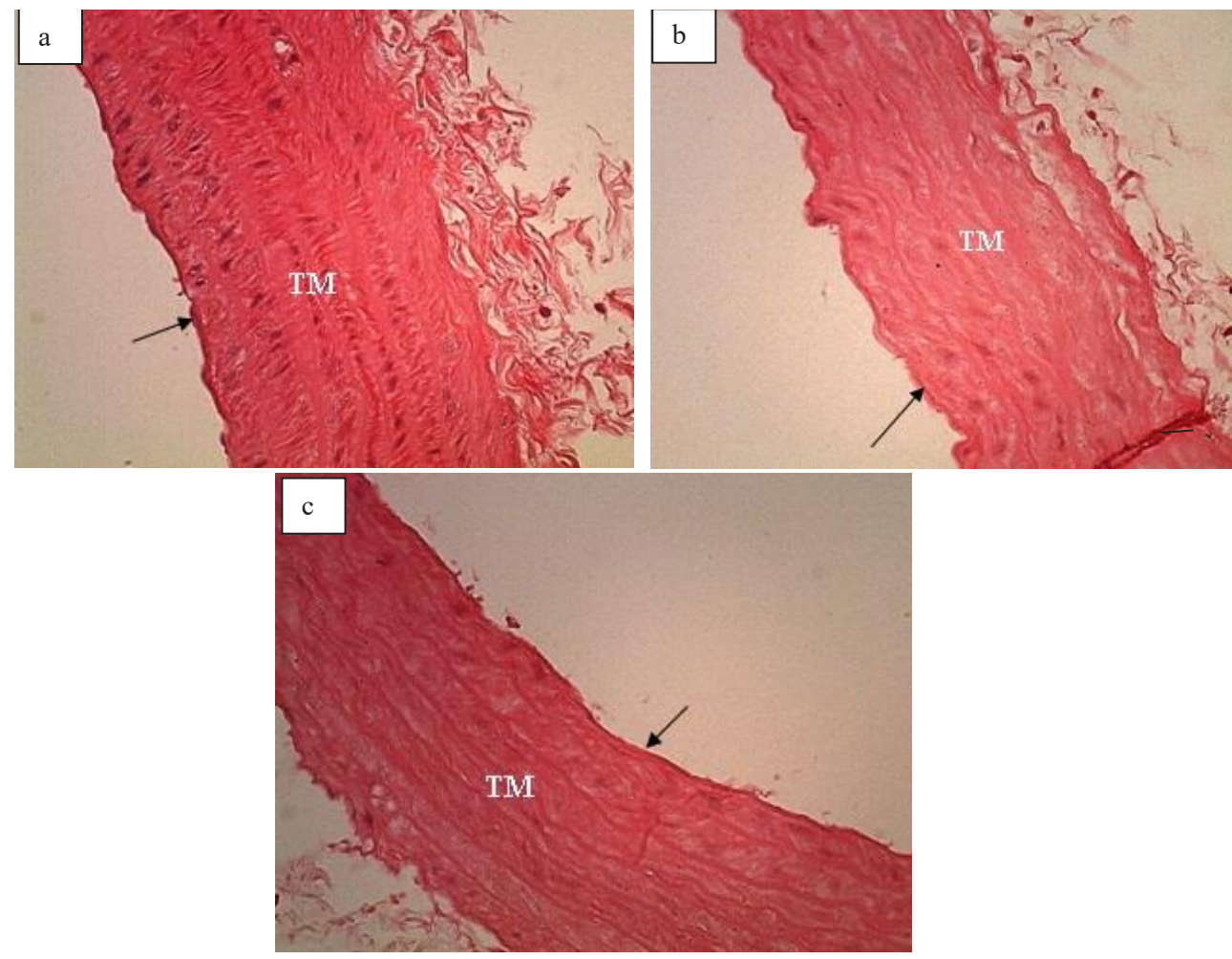

FIGURE 3. Cross section of aortic tissue: (a) G3- black arrow shows the existence of a thicker layer foam cells, (b) G4- black arrow shows bulge of foam cells, and (c) G5- black arrow shows a thinner layer of foam cells. Tunica media (TM) in all images show an enlargement (Magnification: 40×) (scale bar: $200 \mu \mathrm{m}$ )
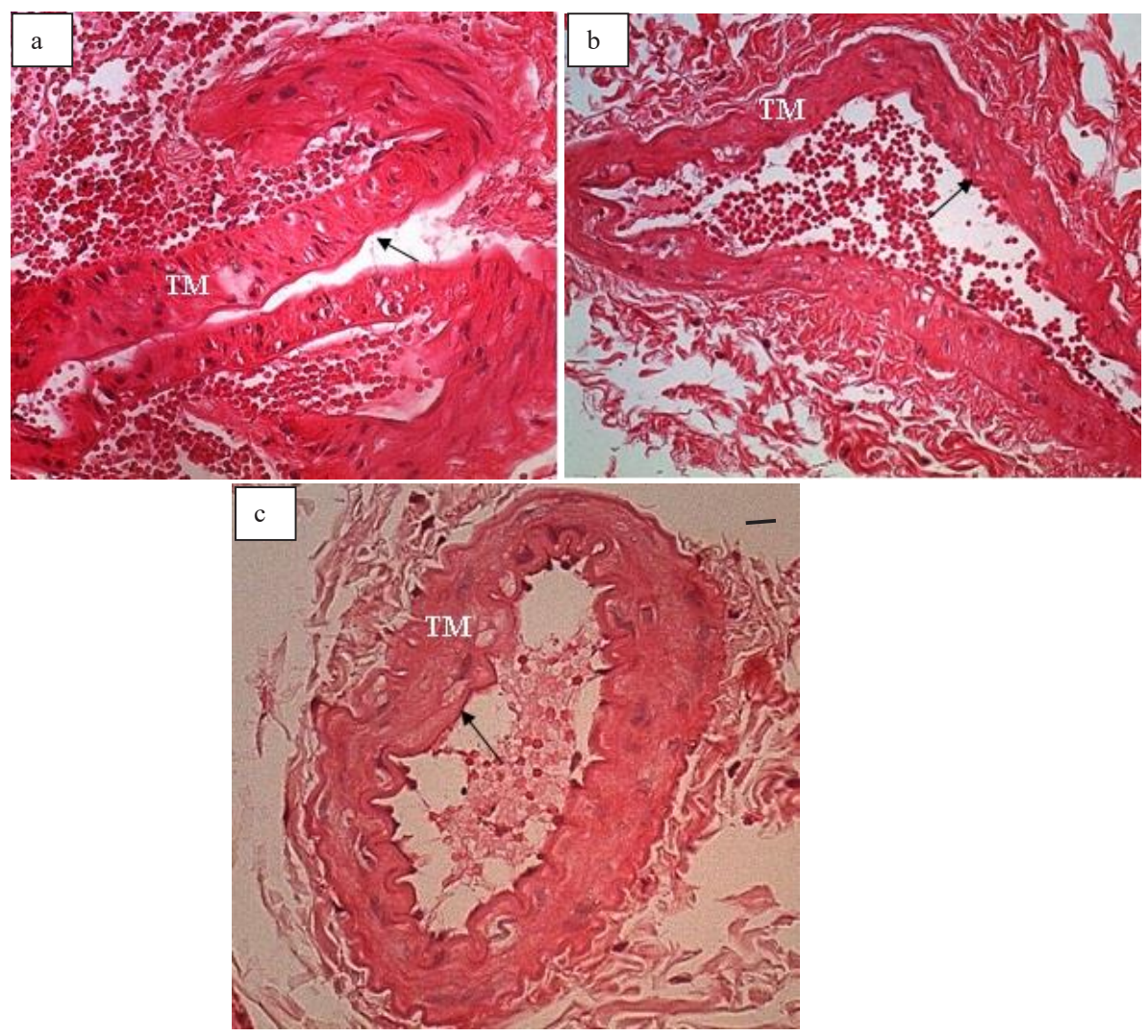

FIGURE 4. Cross section of aortic tissue: (a) G6, (b) G7, and (c) G8. Tunica media (TM) shows an enlargement for G6 to G8. The black arrows in all the images show the foam cell layer (Magnification: 40×) (scale bar: $200 \mu \mathrm{m}$ ) 
Figure 4(a) - 4(c) represented the prevention groups (G6 to G8) with improved conditions compared to treatment groups. Comparing the groups; treatment (G3G5) and prevention (G6-G8), TAR tissue structure was found to be in a better condition following administration of $\mathrm{CA} /$ simvastatin in the prevention groups. Both $\mathrm{CA}$ and simvastatin showed potential to prevent or lower the severity of tissue damage scale due to cholesterol accumulation. Both also managed to reduce TM enlargement (compared to G2 to G5) which has assisted TAR to dilate when challenged with Ach. These findings were as reported by previous research on treated hypercholesterolemic rats using extract of Lagenaria siceraria. Atheromatous lesion in the rat aortic tissue was found to be less severe compared to untreated rats (Rajput et al. 2014).

\section{CONCLUSION}

CA of $P$. pulmonarius was able to reduce the serum total cholesterol level in hypercholesterolemic-induced rat. The treatment groups unfortunately have severe damage due to cholesterol accumulation and administration of CA and simvastatin did not serve any improvement to the observed tissue segments.

Overall, it could be suggested that CA works well in reducing or normalizing the cholesterol level as shown in both treatment and prevention groups. The use of CA as preventive treatment also showed its potential to improve the aortic tissue structure and in certain ways showed a positive impact towards vasodilation. The exact mechanism however, is an interesting area to be further explored.

\section{ACKNOWLEDGEMENTS}

The authors would like to thank Universiti Malaya for

\section{REFERENCES}

Abdullah, N., Ismail, S.M., Aminudin, N., Shuib, A.S. \& Lau, B.F. 2012. Evaluation of selected culinary medicinal mushrooms for antioxidant and ACE inhibitory activities. Evidence-Based Complementary and Alternative Medicine 2012: Article ID. 464238.

Abidin, M.H.Z., Abdullah, N. \& Abidin, N.Z. 2016. Protective effect of antioxidant extracts from grey oyster mushroom, Pleurotus pulmonarius (Agaricomycetes) against human low-density lipoprotein oxidation and aortic endothelial cell damage. International Journal of Medicinal Mushrooms 18(2): 109-121.

Ahmadi, K.G.S., Wulansari, A., Subroto, Y. \& Estiasih, T. 2017. Protective effect of food products enriched with unsaponifiable matter from palm fatty acid distillate on the aorta of hypercholesterolemic rats. Journal of Applied Pharmaceutical Science 7(12): 90-96.

Alam, N., Yoon, K.N., Lee, J.S., Cho, H.J., Shim, M.J. \& Lee, T.S. 2011. Dietary effect of Pleurotus eryngii on biochemical function and histology in hypercholesterolemic rats. Saudi Journal of Biological Sciences 18(4): 403-409.

Anwar, H., Suchodoiski, J.S., Ullah, M.I., Shabbir, M.Z., Mustafa, I. \& Sohail, M. 2019. Shiitake culinary-medicinal mushroom, Lentinus edodes (Agaricomycetes) supplementation alters gut microbiome and corrects dyslipidemia in rats. International Journal of Medicinal Mushrooms 21(1): 79-88.

Berkban, T., Boonpram, P., Bunbupha, S., Welbat, J., Kukongviriyapan, U., Kukongviriyapan, V., Pakdeechote, P. \& Prachaney, P. 2015. Ellagic acid prevents L-NAMEinduced hypertension via restoration of eNOS and p47phax expression in rats. Nutrients 7(7): 5265-5280.

Bhutia, R.D., Khandelwal, B., Sherpa, M.L. \& Singh, T.A. 2019. Oxidation products of DNA, lipid and protein among the individuals progressing towards metabolic syndrome. Indian Journal of Biochemistry and Biophysics 56(2): 155-161.

Boonsong, S., Wanwimol, K.W. \& Pongtep, W.P. 2016. Antioxidant activities of extracts from five edible mushrooms using different extractants. Agriculture and Natural Resources 50(2): 89-97.

Carrasco-Gonzalez, J.A., Serna-Saldivar, S.O. \& GutiérrezUribe, J.A. 2017. Nutritional composition and nutraceutical properties of the Pleurotus fruiting bodies: Potential use as food ingredient. Journal of Food Composition and Analysis 58: 69-81.

Cheah, I.K., Tang, R., Ye, P., Yew, T.S.Z., Lim, K.H.S. \& Halliwell, B. 2016. Liver ergothioneine accumulation in a guinea pig model of non-alcoholic fatty liver disease. A possible mechanism of defence? Free Radical Research 50(1): 14-25.

Chen, H., Li, S., Wang, P., Yan, S., Hu, L., Pan, X., Yang, C. \& Leung, G.P. 2014. Endothelium-dependent and -independent relaxation of rat aorta induced by extract of Schizophyllum commune. Phytomedicine 21(11): 1230-1236.

Choi, J.H., Kim, D.W., Kim, S. \& Kim, S.J. 2017. In vitro antioxidant and in vivo hypolipidemic effects of the king oyster culinary-medicinal mushroom, Pleurotus eryngii var. Ferulae DDL01 (Agaricomycetes), in rats with high-fat dietinduced fatty liver and hyperlipidemia. International Journal of Medicinal Mushrooms 19(2): 107-119.

Correa, R.C.G., Brugnari, T., Bracht, A., Peralta, R.M. \& Ferreira, I.C.F.R. 2016. Biotechnological, nutritional and therapeutic uses of Pleurotus spp. (oyster mushroom) related with its chemical composition: A review on the past decade findings. Trends in Food Science \& Technology 50: 103-117.

de Miranda, A.M., Rossoni Jr., J.V., Souza, S.E.L., Dos Santos, R.C., Silva, M.E. \& Pedrosa, M.L. 2016. Agaricus brasiliensis (sun mushroom) affects the expression of genes related to cholesterol homeostasis. European Journal of Nutrition 56(4): 1707-1717. 
Deiana, M., Rosa, A., Casu, V., Piga, R., Assunta, D.M. \& Aruoma, O.I. 2004. L-ergothioneine oxidative damage in the kidney and liver of rats in vivo: Studies upon the profile of polyunsaturated fatty acids. Clinical Nutrition 23(2): 183-193.

Devipriya, N., Sudhher, A.R. \& Menon, V.P. 2007. Doseresponse effect of ellagic acid on circulatory antioxidants and lipids during alcohol-induced toxicity in experimental rats. Fundamental in Clinical Pharmacology 21(6): 621-630.

Dianita, R., Jantan, I., Jalil, J. \& Amran, A.Z. 2016. Effects of Labisia pumila var alata extracts on the lipid profile, serum antioxidant status and abdominal aorta of high-cholesterol diet rats. Phytomedicine 23(8): 810-817.

Dikshit, P., Tyagi, M.K., Shukla, K., Gambhir, J.K. \& Shukla, R. 2016. Antihypercholesterolemic and antioxidant effect of sterol rich methanol extract of stem of Musa sapientum (banana) in cholesterol fed Wistar rats. Journal in Food Science \& Technology 53(3): 1690-1697.

Ding, Y., Zhang, B., Zhou, K.Y., Chen, M.C., Wang, M.M., Jia, Y.Y., Song, Y., Li, Y.W. \& Wen, A.D. 2014. Dietary ellagic acid improves oxidant-induced endothelial dysfunction and atherosclerosis: Role of Nrf2 activation. International Journal of Cardiology 175(3): 508-514.

Ey, J., Schomig, E. \& Taubert, D. 2007. Dietary sources and antioxidant effects of ergothioneine. Journal of Agricultural and Food Chemistry 55(16): 6466-6474.

Fombang, E.N., Lobe, E.E. \& Mbodunf, M.F. 2016. Pleurotus florida aqueous extracts and powder influence lipid profile and suppress weight gain in rat fed high cholesterol diet. Journal of Nutrition and Food Science 6(2): 1-7.

Gil-Ramirez, A., Caz, V., Smiderle, F.R., Martin-Hernandez, R., Largo, C., Tabernero, M., Marín, F.R., Iacomini, M., Reglero, G. \& Soler-Rivas, C. 2016. Water-soluble compounds from Lentinula edodes influencing the HMG-CoA reductase activity and the expression of genes involved in the cholesterol metabolism. Journal of Agricultural and Food Chemistry 64(9): 1910-1920.

Guillamón, E., García-Lafuente, A., Lozano, M., D’Arrigo, M., Rostagno, M.A., Villares, A. \& Martínez, J.A. 2010. Edible mushrooms: Role in the prevention of cardiovascular diseases. Fitoterapia 81(7): 715-723.

Jeong, S.C., Jeong, Y.T., Yang, B.K., Islam, R., Koyyalamudia, S.R., Panga, G., Choa, K.Y. \& Song, C.H. 2010. White button mushroom (Agaricus bisporus) lowers blood glucose and cholesterol levels in diabetic and hypercholesterolemic rats. Nutrition Research 30(1): 49-56.

Kang, I., Buckner, T., Shay, N.F., Gu, L. \& Chung, S. 2016. Improvements in metabolic health with consumption of ellagic acid and subsequent conversion into urolithins: Evidence and mechanism. Advances in Nutrition 7(5): 961-972.

Khatun, K., Mahtab, H., Khanam, P.A., Sayeed, M.A. \& Khan, K.A. 2007. Oyster mushroom reduced blood glucose and cholesterol in diabetic subjects. Mymensigh Medical Journal 16(1): 94-99.
Koon, C.M., Fong, S., Wat, E., Wang, Y.P., Cheung, W.S.D., Lau, B.S.C., Leung, O.C., Sun, H.D., Zhao, Q.S. \& Fung, K.P. 2014. Mechanisms of the dilator action of the Erigerontis herba on rat aorta. Journal of Ethnopharmology 155(3): 1561-1567.

Li, R.W.S., Yang, C., Sit, A.S.M., Kwan, Y.W., Lee, S.M.Y., Hoi, M.P.M., Chan, S.W., Hausman, M., Vanhoutte, P.M. \& Leung, G.P.H. 2014. Uptake and protective effects of ergothioneine in human endothelial cells. The Journal of Pharmacology \& Experimental Therapeutics 350(3): 691-700.

Manoharan, S., Shuib, A.S., Abdullah, N., Ashrafzadeh, A. \& Kabir, N. 2018. Gly-Val-Arg, an angiotensin-1-converting enzyme inhibitory tripeptide ameliorates hypertension on spontaneously hypertensive rats. Process Biochemistry 69: 224-232.

Matz, R.L., Schott, C., Stoclet, J.C. \& Andriansitohaina, R. 2000. Age-related endothelium dysfunction with respect to nitric oxide, endothelium-derivedhyperpolarizing factor and cyclooxygenase products. Physiological Research 49(1): 11-18.

Murray, M.T. 2009. What the Drug Companies Won't Tell You and Your Doctor Doesn't Know: The Alternative Treatments That May Change Your Life--and the Prescriptions That Could Harm You. New York: Simon and Schuster. pp. 1-352.

Niazmand, S., Elahe, F., Maryam, M. \& Seyed, M.M. 2014. Endothelium-independent vasorelaxant effects of hydroalcoholic extract from Nigella sativa seed in rat aorta: The role of $\mathrm{CA}^{2+}$ and $\mathrm{K}^{+}$channels. Biomed Research International 2014: 247054.

Park, T., Oh, J. \& Lee, K. 1999. Dietary taurine or glycine supplementation reduces plasma and liver cholesterol and triglyceride concentrations in rats fed a cholesterol-free diet. Nutrition Research 19(12): 1777-1789.

Polyzos, K.A. \& Ketelhuth, D.F.J. 2015. The role of the kynureneine pathway of tryptophan metabolism in cardiovascular disease: An emerging field. Hamostaseologie 35(2): 128-136.

Qu, Z., Zhang, J., Gao, W., Chen, H., Guo, H., Wang, T., Li, H. \& Liu, C. 2014. Vasorelaxant effects of Cerebralcare Granule $\AA$ are mediated by NO/cGMP pathway, potassium channel opening and calcium channel blockade in isolated rat thoracic aorta. Journal of Ethnopharmacology 155(1): 572-579.

Rajput, M.S., Balekar, N. \& Jain, D.K. 2014. Lagenaria siceraria ameliorates atheromatouslesions by modulating HMG$\mathrm{CoA}$ reductase and lipoprotein lipase enzymes activity in hypercholesterolemic rats. Journal of Acute Disease 3(1): 14-21.

Roncero-Ramos, I. \& Delgado-Andrade, C. 2017. The beneficial role of edible mushrooms in human. Current Opinion in Food Science 14: 122-128.

Sharma, S., Mishra, V. \& Srivastava, N. 2020. Protective effect of Trigonella foenum-graecum and Cinnamomum zeylanicum against diabetes induced oxidative DNA damage in rats. Indian Journal of Biochemistry and Biophysics 57(1): 15-26. 
Slaoui, M. \& Fiette, L. 2011. Histopathology procedures: From tissue to histopathological evaluation. In Drug Safety Evaluation, edited by Gautier, J.C. New Jersey: Humana Press. pp. 69-82.

Smith, E., Ottoson, F., Hellstrands, S., Ericson, U., OrhoMelander, M., Fernendez, C. \& Melander, O. 2020. Ergothioneine is associated with reduced mortality and decreased risk of cardiovascular disease. Heart 106(9): 691-697.

Song, P., Ramprasath, T., Wang, H. \& Zhou, M.H. 2017. Abnormal kynurenine pathway of tryptophan catabolism in cardiovascular diseases. Cellular and Molecular Life Sciences 74(16): 2899-2916.

Yilmaz, B. \& Usta, C. 2013. Ellagic acid-induced endotheliumdependent and endothelium-independent vasorelaxation in rat thoracic aortic rings and the underlying mechanism. Phytotherapy Research 27(2): 285-289.
Mushroom Research Centre Institute of Biological Sciences Faculty of Science

Universiti Malaya

50603 Kuala Lumpur, Federal Territory

Malaysia

*Corresponding author; email: hanizaaminudin@um.edu.my

Received: 15 January 2021

Accepted: 18 May 2021 